STUDIA UBB PSYCHOL.-PAED., LXVI, 1, 2021, p. 77 - 90

(Recommended Citation)

DOI:10.24193/subbpsyped.2021.1.04

\title{
THE RELATIONSHIP BETWEEN BASIC PSYCHOLOGICAL NEEDS, MOTIVATION AND SELF-EFFICACY IN A SAMPLE OF SECONDARY AND HIGH-SCHOOL CHILDREN FROM CLUJ-NAPOCA, ROMANIA
}

\author{
ANTONIA MĂRINCAȘ 1 , DANIELA DUMULESCU ${ }^{1}$, \\ SEBASTIAN PINTEA ${ }^{1}$, NICOLAE-ADRIAN OPRE ${ }^{1 *}$
}

\begin{abstract}
Motivation is the key force that drives the individual. According to Self-Determination Theory (Ryan \& Deci, 2000), human motivation is regulated by the degree to which personal intentions are autonomous or controlled. On the other hand, human behaviour is determined by three basic needs (competence, autonomy and relatedness) which contribute to intrinsic motivation and psychological health. This study has investigated the relationship between basic psychological needs and different types of motivation in an educational context. The research included a large sample of school students from $5^{\text {th }}$ to $12^{\text {th }}$ grade, enrolled in two schools from Cluj-Napoca, Romania $(N=363)$. All participants completed an online survey aimed to evaluate student's fulfilment of their basic psychological needs, their motivation and self-efficacy regarding Romanian literature lessons. Results showed that autonomy, competence and relatedness correlated with intrinsic motivation. Moreover, the regression results showed that basic psychological needs predicted half of the variance in intrinsic motivation. The outcomes of this study also revealed that girls displayed higher scores on self-efficacy, autonomy and identified regulation as compared to boys.
\end{abstract}

Keywords: self-determination theory, self-regulated learning, intrinsic motivation, basic psychological needs, autonomy, competence, relatedness, self-efficacy

ZUSAMMENFASSUNG. Motivation ist die Schlüsselkraft welche das menschliche Wesen aktiviert. Laut der Selbstbestimmungstheorie (Ryan \& Deci, 2000), wird die menschliche Motivation durch den Grad der Autonomie oder Kontrolle der persönlichen Absichten reguliert.

1 Department of Psychology, Babes-Bolyai University, Cluj-Napoca, Romania

* Corresponding author: adrianopre@psychology.ro 
ANTONIA MĂRINCAȘ, DANIELA DUMULESCU, SEBASTIAN PINTEA, NICOLAE-ADRIAN OPRE

Andererseits wird das menschliches Verhalten durch drei Grundbedürfnisse (Kompetenz, Autonomie, Bezogenheit) bestimmt, die zur intrinsischen Motivation und psychischen Gesundheit beitragen. In dieser Studie wurde die Beziehung zwischen psychologischen Grundbedürfnissen und Motivationstypen im Bildungskontext an einer großen Stichprobe von Schülern der 5. bis 12 . Klasse untersucht, die in zwei Schulen aus Cluj-Napoca, Rumänien, eingeschrieben waren $(\mathrm{N}=363)$. Alle Teilnehmer haben eine Online-Umfrage ausgefüllt, die darauf abzielte, die Befriedigung ihrer psychologischen Grundbedürfnisse, Motivation und Selbstwirksamkeit innerhalb des rumänischen Literaturunterrichts $\mathrm{zu}$ bewerten. Die Ergebnisse zeigen, dass Autonomie, Kompetenz und Verbundenheit mit intrinsischer Motivation korrelieren. Darüber hinaus sagt Autonomie den größten Teil der Variante der intrinsischen Motivation voraus. Die Ergebnisstudie zeigt auch, dass Mädchen im Vergleich zu Jungen höhere Werte bei Selbstwirksamkeit, Autonomie und Selbstbestimmung aufweisen.

Stichworte: Selbstbestimmungstheorie, selbstreguliertes Lernen, intrinsische Motivation, psychologische Bedürfnisse, Autonomie, Kompetenz, Bezogenheit, Selbstwirksamkeit

\section{Introduction}

Both teachers and parents often evaluate students' school performance only by looking at their school grades. Given this aspect, we aimed to analyze in more depth the predictors of learning motivation with direct impact on students' academic results and school performance in a public educational setting.

\section{Basic psychological needs in Self-Determination Theory}

Motivation is a central force that influences all human activities. When performing different actions, people express different levels of interest, engagement and persistence (Ryan \& Deci, 2000a). Self-Determination Theory (SDT) is a well-known framework for understanding the motivation towards learning (Ryan \& Deci, 2000). Before this theory emerged, learning motivation was explained based on a dichotomic division as intrinsic and extrinsic motivation. Ryan and Deci (2000) revealed that motivation can be seen on a continuum ranging from amotivation to extrinsic motivation and intrinsic motivation. People are naturally prone towards psychological growth, but this requires supportive environmental conditions. The three basic needs that must be satisfied are the need for autonomy, competence and relatedness. Autonomy refers to the sense of initiative in an action, competence refers to the idea of being successful and having a feeling of mastery, and relatedness refers to a feeling of belonging and connection with others (Ryan \& Deci, 2020). 
THE RELATIONSHIP BETWEEN BASIC PSYCHOLOGICAL NEEDS, MOTIVATION AND SELF-EFFICACY IN A SAMPLE OF SECONDARY AND HIGH-SCHOOL CHILDREN FROM CLUJ-NAPOCA, ROMANIA

\section{Self-Determination Theory's Taxonomy of Motivation}

According to Ryan and Deci (1985), motivational orientations can vary depending on a person's level of self-determination and can be seen on a continuum with six different levels. First is amotivation, then extrinsic motivation which has itself four different levels (external regulation, introjected regulation, identified regulation and integrated regulation) and intrinsic motivation. Amotivation is characteristic to people who have low perceived competence and are not motivated intrinsically or extrinsically. Such individuals do not find a meaning in taking any action (Ryan \& Deci, 2000a).

Extrinsic motivation is characterized by engaging in an activity to obtain an outcome and not performing it for the pleasure of that activity. External regulation is a type of motivation that involves an external source of energy for a person to take an action, such as executing an action in order to obtain a reward or to avoid a punishment. Introjected regulation is more selfdetermined than external regulation and the pressure source is internal and not based on personal choice. The focus of this type of motivation is on receiving self-approval and others' approval. Therefore, the individual is doing the activity in order to avoid feelings of guilt, anxiety, failure or shame (Ryan \& Deci, 2020). This type of motivation often takes the form of ego-evolvement. Identified regulation is somewhat internal and displaying self-endorsement of goals. Hence, even if the action itself is not always interesting the person understands the value of the activity. The most autonomous form of extrinsic motivation is integrated regulation, in which the individual has internalized the reasons for performing a certain action.

Intrinsic motivation is highly self-determined with the person being interested in the activity and enjoying the process of doing it without necessarily having an external reason (see Figure 1).

Self-Determination Theory suggests that identified regulation and intrinsic motivation are autonomous forms of motivation (Vansteenkiste et al., 2010), whereas external regulation and introjected regulation are controlled and less self-determined forms of motivation.

Students' perceptions of autonomy, competence and relatedness were previously positively associated with higher intrinsic motivation (Standage et al., 2005) as well as higher school satisfaction and improved subjective wellbeing (Tian et al., 2014). Several studies have shown that intrinsic motivation was associated with higher academic performance (Taylor et al., 2014) and better student engagement in the learning process (Froiland \& Worrell, 2016). The degree of internalization determines the level of autonomy or selfdetermination. Intrinsic motivation and identified regulation are correlated 
with better social functioning, greater persistence and psychological wellness in school and sports (Black \& Deci, 2000), more positive emotions and better grades (Guay et al., 2010). Identified regulation and intrinsic motivation are less differentiated (Kusurkar et al., 2013), both having in common the selfendorsement of goals (Deci \& Ryan, 1985).

Fig. 1. Self-Determination Theory's Taxonomy of Motivation (Ryan \& Deci, 2020)

\begin{tabular}{|c|c|c|c|c|c|c|}
\hline \multicolumn{7}{|c|}{ Self-Determination Theory's Taxonomy of Motivation } \\
\hline Motivation & AMOTIVATION & & $\begin{array}{l}\text { EXI } \\
\text { MOT }\end{array}$ & $\begin{array}{l}\text { RINSIC } \\
\text { VATION }\end{array}$ & & $\begin{array}{l}\text { INTRINSIC } \\
\text { MOTIVATION }\end{array}$ \\
\hline \multirow[t]{2}{*}{$\begin{array}{l}\text { Regulatory } \\
\text { Style }\end{array}$} & \multirow[b]{3}{*}{$\begin{array}{l}\text { - Lack of perceived } \\
\text { competence, } \\
\text { - Lack of value, or } \\
\text { - Nonrelevance }\end{array}$} & $\begin{array}{c}\text { External } \\
\text { Regulation }\end{array}$ & Introjection & Identification & Integration & \multirow{4}{*}{$\begin{array}{ll}\text { - Interest } \\
\text { - Enjoyment } \\
\text { - Inherent } \\
\text { satisfaction }\end{array}$} \\
\hline & & \multicolumn{4}{|c|}{ Internalization } & \\
\hline Attributes & & $\begin{array}{l}\text { - External } \\
\text { rewards or } \\
\text { punishments } \\
\text { - Compliance } \\
\text { - Reactance }\end{array}$ & $\begin{array}{l}\text { Ego } \\
\text { involvement } \\
\text { - Focus on } \\
\text { approval from } \\
\text { self and } \\
\text { others }\end{array}$ & $\begin{array}{l}\text { - Personal } \\
\text { importance } \\
\text { - Conscious valuing } \\
\text { of activity } \\
\text { - Self- } \\
\text { endorsement of } \\
\text { goals }\end{array}$ & 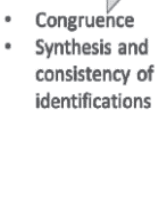 & \\
\hline $\begin{array}{l}\text { Perceived } \\
\text { Locus of } \\
\text { Causality }\end{array}$ & Impersonal & External & $\begin{array}{l}\text { Somewhat } \\
\text { External }\end{array}$ & $\begin{array}{l}\text { Somewhat } \\
\text { Internal }\end{array}$ & Internal & \\
\hline
\end{tabular}

Studies have shown that girls have a higher motivation when it comes to learning foreign languages, whereas boys show less learning persistence (Carreira, 2011; Oga-Baldwin \& Nakata, 2014). When it comes to external regulation for learning languages, this need is more prevalent in boys as opposed to girls (Oga-Baldwin \& Fryer, 2020).

More autonomous forms of motivation will increase students' learning, engagement and wellness. This type of motivation will be stimulated when the basic psychological needs of a student are satisfied through the involvement of teachers and parents (Ryan \& Deci, 2020). Students' participation in school depends on how much teachers and the school environment satisfy their autonomy, competence and relatedness (Deci \& Ryan, 2012), which then have effects on their self-efficacy and achievements. 
THE RELATIONSHIP BETWEEN BASIC PSYCHOLOGICAL NEEDS, MOTIVATION AND SELF-EFFICACY IN A SAMPLE OF SECONDARY AND HIGH-SCHOOL CHILDREN FROM CLUJ-NAPOCA, ROMANIA

\section{Self-efficacy in school}

Self-efficacy is a concept introduced by Albert Bandura and it refers to one's perceived capabilities for performing actions at proposed levels (Wentzel \& Miele, 2016). It was also defined as "people's judgments of their capabilities to organize and execute courses of action required in order to attain designated types of performances" (Bandura, 1986, p. 391). Academic self-efficacy refers to the perceived ability to succeed in learning activities in general and is differentiated from the ability to successfully master a specific academic subject (Dorfman \& Fortus, 2019). General self-efficacy refers to a global confidence a person has in his/her abilities across a large variety of situations. Self-efficacy sources can be mastery performances, vicarious experiences, forms of social persuasions ("I know you are capable of doing that") and physiological and emotional states (such as anxiety, stress etc.) (Dogan, 2015).

Researchers found that self-efficacy for science tends to decline in the middle school for girls more than for boys (Rittmayer \& Beier, 2008; Barth et al., 2011; Rice et al., 2013). In contrast, girls have higher self-efficacy in languages compared to boys. Children who study in an urban school have higher self-efficacy compared to those from rural regions (Mahyuddin et al., 2006). Self-efficacy was positively related to intrinsic motivation (Zimmerman \& Kitsantas, 1997). Also, some studies have shown that self-efficacy in English language correlates with intrinsic motivation and that male students have greater intrinsic interest towards the mathematics discipline (Fan \& Williams, 2009). Self-efficacy has a positive effect on academic learning, self-regulation and achievement (Schunk \& Zimmerman, 2012), and people with a high level of self-efficacy prefer thorough learning to superficial learning (Liem et al., 2008). In contrast, some studies show that academic self-efficacy moderately correlates with academic performance (Dogan, 2015; Honicke \& Broadbent, 2016).

It is very important that the classroom environment supports individual mastery, self-improvement and collaboration as well as gives attention to the effort one puts in an activity. Students' individual interests help them maintain or increase their positive perceptions towards self-efficacy (Anderman \& Midgley, 1997; Schunk \& Meece, 2006).

\section{Current study}

The main goal of the present study is to investigate the association between basic psychological needs (autonomy, competence and relatedness), motivational orientations (intrinsic motivation, identified regulation, introjected regulation, and external regulation) and self-efficacy for learning. 
The study hypotheses are:

1. Basic psychological needs (autonomy, competence and relatedness) will predict intrinsic motivation for learning;

2. Self-efficacy for learning will be positively correlated with intrinsic motivation;

3. Self-efficacy for learning will be positively correlated with integrated regulation;

4. Self-efficacy for learning will negatively correlate with external regulation;

5. Girls will have higher self-efficacy than boys;

6. Girls will have a higher intrinsic motivation than boys;

7. Boys will have a higher external motivation than girls.

\section{Method}

\section{Participants and procedure}

Participants in this study were 363 middle and high school adolescents with an average age of $15.54(S D=2.00)$. Regarding gender distribution, 251 were girls and 112 boys. In addition, 299 students lived in urban areas and 64 in rural areas. Participants were $5^{\text {th }}$ to $12^{\text {th }}$ grade and were attending 2 public schools, 331 children from one traditional public school and 32 children from an alternative Waldorf school, both located in Cluj-Napoca, Romania. See Table 1 for demographic data.

Table 1. Demographic data

\begin{tabular}{ccc}
\hline Variable & N $=\mathbf{3 6 3}$ & SD \\
\hline Gender & 251 & \\
Female & 112 & \\
Male & 15.54 & 2.00 \\
Age & & \\
Area & 299 & \\
Urban & 64 & \\
Rural & 331 & \\
School type & 32 & \\
Public & & \\
Waldorf &
\end{tabular}


THE RELATIONSHIP BETWEEN BASIC PSYCHOLOGICAL NEEDS, MOTIVATION AND SELF-EFFICACY IN A SAMPLE OF SECONDARY AND HIGH-SCHOOL CHILDREN FROM CLUJ-NAPOCA, ROMANIA

Schools were contacted and asked to participate in the study. After receiving approval from school boards, parental written consent was obtained before data collection began. Confidentiality and anonymity were guaranteed, and the student's participation was voluntary.

The questionnaires were administrated online at the beginning of the pandemic period in March 2020 and took approximately 10 minutes to complete. Participants completed the survey outside of their regular school time. The students were asked to complete an online questionnaire focused on their academic self-regulation strategies, their basic psychological needs satisfaction (regarding the academic subject of Romanian literature lessons) and academic self-efficacy.

\section{Instruments}

Basic Psychological Needs. The questionnaire is based on the principles of Self-Determination Theory and it measures students' basic psychological needs. The instrument was translated by the authors from the standard version of BPNS (adapted from Carreira, 2012) and were adapted to refer to Romanian language. The items were translated using a back-translation procedure. The basic psychological needs were assessed through the following 3 scales with 4 items each measuring respectively students' perceptions of autonomy (e.g., "I am willing to participate in Romanian lessons"), students' perceptions of competence (e.g., "I consider myself good at Romanian language"), and students' perceptions of relatedness (e.g., "Everybody in the class enjoys Romanian lessons"). Cronbach's alpha values of autonomy, competence and relatedness were, respectively, .81, .78 and .71. For our sample, the Cronbach's alpha values were .87 for autonomy, .73 for competence and .74 for relatedness.

Academic Self-Regulation Questionnaire. The Romanian version of the instrument was translated by the authors from the standard version of SRQ-A (based on Ryan \& Connell, 1989) and were adapted to refer to Romanian language. The items were translated using a back-translation procedure. The responses to each item are on a 4-point scale, where "Very true" is scored 4 and "Not at all true" is scored 1. The SRQ-A has four subscales: external regulation ("I do my homework because that's what I'm supposed to do"), introjected regulation ("I do my homework because I want the teacher to think I'm a good student"), identified regulation ("I do my homework because I want to understand the subject"), and intrinsic motivation ("I enjoy doing my homework"). The Alpha Cronbach values in our study were .75 for external regulation, .79 for introjected regulation, .86 for internal regulation and .87 for intrinsic regulation. 
ANTONIA MĂRINCAȘ, DANIELA DUMULESCU, SEBASTIAN PINTEA, NICOLAE-ADRIAN OPRE

Self-efficacy from MSLQ. The Motivated Strategies for Learning Questionnaire (MSLQ) made by Pintrich et al. (1993) is a self-report scale used to identify students' motivational orientations. Items for self-efficacy are scored on a 7-point Likert scale, where 1 is "not at all true for me" and 7 (very true for me). The coefficient Alpha is .93 for self-efficacy. In our study, the Alpha Cronbach was also 93.

\section{Data analysis and results}

The data collected was analysed with SPSS 21.1 Statistics program. To test the first hypothesis, we performed a linear regression analysis. The results showed that basic psychological needs (autonomy, relatedness and competences) predicted intrinsic motivation $\left(r^{2}=.53, p<.001\right)$. Hence, the model explained $53 \%$ of the variance in intrinsic motivation $(\beta$ coefficients were .42 for autonomy, .20 for competence and .22 for relatedness, $p<.001$ ). The second, third and fourth hypotheses were tested by performing a correlational analysis (see Table 2) and the results indicated that self-efficacy was positively related to intrinsic regulation $(r=.41, p<.01)$ and identified regulation $(r=.29, p<.01)$, and negatively related to external regulation $(r=.-14, p<.01)$.

Table 2. Correlations between studied variables

\begin{tabular}{lcccc}
\hline & 1 & 2 & 3 & 4 \\
\hline 1. Self-efficacy (MSLQ total score) & - & & & \\
2. Intrinsic regulation (SRQ) & $.417^{* *}$ & - & & \\
3. Identified regulation (SRQ) & $.295^{* *}$ & .698 & - & - \\
4. Introjected regulation (SRQ) & .071 & .373 & .488 & .578 \\
5. External regulation (SRQ) & $-.142^{* *}$ & .041 & .227 & \\
\hline
\end{tabular}

Note. ${ }^{* *} p<.001, N=363$, SRQ = Self-Regulation Questionnaire; MSLQ = Motivated

Strategies for Learning Questionnaire

Regarding gender differences, the t-tests revealed significant differences between female students and male students on learning self-efficacy $(t=2.48$, $p=.01)$, with girls having a higher self-efficacy $(M=46.96, S D=8.7)$ than boys $(M=44.38, S D=9.9)$; Cohen's $d$ was .27 . In addition, girls reported higher identified regulation than boys $\operatorname{did}(t=2.63, p=.01 ; M=22.41, S D=4.56$, $M=20.93, S D=5.67)$ and Cohen's $d$ was .28 . On the other hand, boys reported higher external regulation than girls did $(t=2.08, p=.003 ; M=24.43, S D=5.1$, $M=23.17, S D=5.39$ ) and Cohen's $d$ was .24 . There were no significant differences between boys and girls in introjected regulation scores. 
THE RELATIONSHIP BETWEEN BASIC PSYCHOLOGICAL NEEDS, MOTIVATION AND SELF-EFFICACY IN A SAMPLE OF SECONDARY AND HIGH-SCHOOL CHILDREN FROM CLUJ-NAPOCA, ROMANIA

\section{Discussion}

The present study aimed to explore the relations between basic psychological needs (autonomy, competence, and relatedness), motivational orientations (intrinsic motivation, identified regulation, introjected regulation, and external regulation) and self-efficacy for learning on a sample of secondary and high school students in Romania.

First, our findings revealed that students whose basic psychological needs were fulfilled, had higher intrinsic motivation to learn. More specifically, autonomy, competence and relatedness predicted 53\% of intrinsic motivation for a specific discipline (Romanian Language and Literature), which is in line with previous studies emphasizing the idea that girls are more interested in learning languages. In contrast, boys displayed less curiosity, enjoyment (Carreira, 2011) and engagement (Oga-Baldwin \& Nakata, 2014) in those school subjects.

Second, students with positive beliefs of self-efficacy for learning reported a higher identified and intrinsic motivation. Hence, such students are more able to connect their learning to meaningful goals and find inherent interest in learning. On the other hand, having a high self-efficacy was negatively related to external motivation. Therefore, students who believed in their capabilities to succeed were less prone to be influenced by external rewards and less likely to avoid negative consequences.

Third, another important result of our study reflects gender differences in motivation and self-efficacy. Specifically, regarding self-efficacy, female students reported more positive beliefs about their learning capabilities than male students, which is a finding confirmed in previous studies. In one recent study (Oga-Baldwin \& Fryer, 2020), girls with higher self-efficacy displayed higher identified motivation. In contrast, boys reported lower self-efficacy, which was associated with external regulation for language learning.

Fourth, girls in our study showed a stronger identified regulation than boys, while boys were more externally regulated. More specifically, girls were more able to set meaningful learning goals and to connect their learning with their values, while boys were more motivated to gain external rewards or to avoid negative consequences (Dorfman \& Fortus, 2019). A recent study has shown that girls had a lower level of intrinsic motivation in mathematics but not a lower performance than boys (Lazarides \& Lauermann, 2019). This lower motivation in girls leads to a preference for careers in language-related fields.

Stereotype effects might also contribute to the differences between academic performance and self-perceptions (Steel, 1997). Teachers and parents believe that the mathematics discipline is a "typically male" subject and because of that girls have a lower confidence in their math abilities, despite their high 
achievements. A similar situation might occur with regard to boys' tendency to score lower grades and display lower self-efficacy in language learning (Watt, 2004).

\section{Limits and future directions}

As with any study, both strengths and limitations exist in this research. One strength is the large number of students that were included in this study and also the diverse educational system that they represented as children learned in two different public schools: one traditional and the second, an alternative educational system.

Certain limitations were present in this study. One limitation is the exclusive use of self-report questionnaires, which might increase the subjectivity of the data. One possible solution to counteract for a potential bias due to socially desirable responses would be to collect data from various sources (parents and teachers). At the same time, the gender distribution was not equally represented in our sample, hence future studies could better address this issue.

Moreover, future research could also investigate children's interest for the researched domain because this variable can influence their motivation to learn at this discipline and its' association with students' fulfilment of basic psychological needs. In addition, children's level of depression and anxiety should be taken into account in future studies as it can influence their satisfaction with life and school. Also standardized achievement test scores (e.g., grade point average) could be included to consider the effects generated by motivation on achievement outcomes.

Furthermore, it would be relevant to include more educational systems such as Step by Step, Montessori etc., as Waldorf schools in Romania are state funded and it would be interesting to see whether there are differences between public and private educational systems. Additionally, future studies might use multi-rate designs to improve the sources that can have direct influence on basic psychological needs and on the types of learning motivation (e.g. teachers, parents, peers).

\section{Conclusion}

The present study brings valuable insights into the relations between basic psychological needs, intrinsic motivation and self-efficacy for learning on a sample of Romanian secondary and high school students from Cluj-Napoca, 
THE RELATIONSHIP BETWEEN BASIC PSYCHOLOGICAL NEEDS, MOTIVATION AND SELF-EFFICACY IN A SAMPLE OF SECONDARY AND HIGH-SCHOOL CHILDREN FROM CLUJ-NAPOCA, ROMANIA

Romania. Meeting the needs for autonomy, control and relatedness, significantly improved intrinsic motivation for learning. Our findings emphasise the importance of meeting students' basic psychological needs in school settings. Moreover, student's internal regulation (integrated and intrinsic) was strongly related to high self-efficacy for learning. Last but not least, our study highlighted gender differences in motivation showing the particularities that appear in learning motivation between boys and girls. Hence, girls had higher intrinsic motivation to learn Romanian language, whereas boys where more externally motivated. On a deeper level, one mechanism explaining this difference could be selfefficacy. In our sample, girls had higher self-efficacy for learning as compared to boys, which can explain their better engagement and their internal regulation for learning. Self-efficacy in Romanian language was higher for girls than for boys. In addition, self-efficacy was positively correlated with intrinsic motivation and identified regulation, and negatively correlated with introjected regulation and external motivation. Therefore, students who have a higher self-efficacy would also display intrinsic motivation to study that specific discipline and be less influenced by external motivators.

The results of this study show us the importance of raising awareness among decision makers in schools with regards to upholding students' personal motivation as a way to increase academic engagement and school performance.

Abbreviations: SDT $=$ Self-Determination Theory, SRQ-A = Academic SelfRegulation Questionnaire.

Acknowledgements: This work was possible with the financial support of the Operational Programme Human Capital 2014-2020, under the project number POCU 123793 with the title "Researcher, future entrepreneur - New Generation".

Availability of data and materials: The datasets used and analysed during the current study are available from the corresponding author on reasonable request.

Competing interests: The authors declare that they have no competing interests. 
ANTONIA MĂRINCAȘ, DANIELA DUMULESCU, SEBASTIAN PINTEA, NICOLAE-ADRIAN OPRE

\section{REFERENCES}

Anderman, E. M., \& Midgley, C. (1997). Changes in personal achievement goals and the perceived goal structures across the transition to middle schools. Contemporary Educational Psychology, 22, 269-298.

Bandura, A. (1986). Social foundations of thought and action: A social cognitive theory. Englewood Cliffs, NJ: Prentice-Hall, Inc.

Barth, J., Todd, B., McCallum, D. M., Goldston, M., Guadagno, R. E., Roskos, B., \& Burkhalter, C. (2011). Effects of engaging classroom strategies and teacher support on student outcomes over school transitions. In Proceedings of the American Society for Engineering Education Annual Conference and Exposition. Vancouver, BC, Canada.

Black, A. E., \& Deci, E. L. (2000). The effects of instructors' autonomy support and students' autonomous motivation on learning organic chemistry: A selfdetermination theory perspective, Science education, 84(6), 740-756.

Carreira, J.M. (2011). Relationship between motivation for learning EFL and intrinsic motivation for learning in general among Japanese elementary school students. System 39 (1), 90-102.

Carreira, J.M. (2012). Motivational orientations and psychological needs in EFL learning among elementary school students in Japan. System, 40, 191-202, doi:10.1016/j.system.2012.02.001.

Deci, E. L., \& Ryan, R. M. (1985). Intrinsic motivation and self-determination in human behavior. New York: Plenum Press.

Deci, E. L., \& Ryan, R. M. (2012). Self-determination theory. In P. A. M. Van Lange, A. W. Kruglanski, \& E. T. Higgins (Eds.), Handbook of theories of social psychology, 416436, Sage Publications Ltd. https://doi.org/10.4135/9781446249215.n21.

Dogan, U. (2015). Student Engagement, Academic Self-efficacy, and Academic Motivation as Predictors of Academic Performance. Anthropologist, 20(3), 553-561.

Dorfman, B-S., \& Fortus, D. (2019). Students' self-efficacy for science in different school systems. Journal of Research in Science Teaching, 56 (8), 1-23, https://doi.org/10.1002/tea.21542.

Fan, W., \& Williams, C. M. (2009). The effects of parental involvement on students' academic self-efficacy, engagement and intrinsic motivation. Educational Psychology, 30(1), 53-74, doi:10.1080/01443410903353302.

Froiland, J. M., \& Worrell, F. C. (2016). Intrinsic motivation, learning goals, engagement, and achievement in a diverse high school. Psychology in the Schools, 53(3), 321336.

Guay, F., Chanal, J., Ratelle, C.F., Marsh, H.W., Larose, S., \& Boivin, M. (2010). Intrinsic, identified, and controlled types of motivation for school subjects in young elementary school children. British Journal of Educational Psychology, 80(4), 711735, https://doi.org/10.1348/000709910X499084. 
THE RELATIONSHIP BETWEEN BASIC PSYCHOLOGICAL NEEDS, MOTIVATION AND SELF-EFFICACY IN A SAMPLE OF SECONDARY AND HIGH-SCHOOL CHILDREN FROM CLUJ-NAPOCA, ROMANIA

Honicke, T., \& Broadbent, J. (2016). The Relation of Academic Self-Efficacy to University Student Academic Performance: A Systematic Review. Educational Research Review, 17, 63-84. http://dx.doi.org/10.1016/j.edurev.2015.11.002.

Kusurkar, R. A., Ten Cate, Th. J., Vos, C. M. P., Westers, P., \& Croiset, G. (2013). How motivation affects academic performance: a structural equation modelling analysis. Advances in Health Sciences Education, 18, 57-69.

Lazarides, R., \& Lauermann, F. (2019). Gendered Paths Into STEM-Related and Language-Related Careers: Girls' and Boys' Motivational Beliefs and Career Plans in Math and Language Arts. Frontiers in Psychology, 10, 1-17. https://doi.org/10.3389/fpsyg.2019.01243.

Liem, A.D., Lau, S., \& Nie, Y. (2008). The role of self-efficacy, task value, and achievement goals in predicting learning strategies, task disengagement, peer relationship, and achievement outcome. Contemporary Educational Psychology, 33, 486-512.

Mahyuddin, R., Elias, H., Cheong, L.S., Muhamad, M.F., Noordin, N., \& Abdullah, M.C. (2006). The relationship between students' self-efficacy and their English language achievement. Jurnal Pendidik dan Pendidikan, 21, 61-71.

Oga-Baldwin, W. L. Q., \& Nakata, Y. (2014). Optimizing new language use by employing young learners' own language, ELT Journal, 68(4), 410-421, https://doi.org/10.1093/elt/ccu010.

Oga-Baldwin, W.L.Q., \& Fryer, L.K. (2020). Girls show better quality motivation to learn languages than boys: latent profiles and their gender differences. Heliyon, 6(5), 1-7, https://doi.org/10.1016/j.heliyon.2020.e04054.

Pintrich, P.R., Smith, D.A.F., Garcia, T., \& McKeachie, W.J. (1993). Reliability and Predictive Validity of the Motivated Strategies for Learning Questionnaire (MSLQ). Educational and Psychological Measurement, 53, DOI: 10.1177/0013164493053003024.

Rice, L., Barth, J. M., Guadagno, R. E., Smith, G. P. A., \& McCallum, D. M. (2013). The role of social support in students' perceived abilities and attitudes toward math and science. Journal of Youth and Adolescence, 42(7), 1028-1040.

Rittmayer, A. D., \& Beier, M. E. (2008). Overview: Self-efficacy in STEM. In B. Bogue \& E. Cady (Eds.). Applying Research to Practice (ARP) Resources.

Ryan, R.M., \& Connell, J.P. (1989). Perceived locus of causality and internalization: Examining reasons for acting in two domains. Journal of Personality and Social Psychology, 57(5), 749-761

Ryan, R.M., Connell, J.P., \& Deci, E.L., (1985). A motivational analysis of selfdetermination and self-regulation in education. In: Ames, C., Ames, R. (Eds.), Research on Motivation in Education. The Classroom Milieu, vol. 2. Academic Press, New York, 13-51.

Ryan, R.M., \& Deci, E.L. (2000). Intrinsic and extrinsic motivations: classic definitions and new directions. Contemporary Educational Psychology, 25, 54-67.

Ryan, R.M., \& Deci, E. L. (2000a). Self-determination theory and the facilitation of intrinsic motivation, social development, and well-being. American Psychologist, 55, 68-78. https://doi.org/10.1037//0003-066x.55.1.68. 
ANTONIA MĂRINCAȘ, DANIELA DUMULESCU, SEBASTIAN PINTEA, NICOLAE-ADRIAN OPRE

Ryan, R.M., \& Deci, E.L. (2020). Intrinsic and extrinsic motivation from a self-determination theory perspective: Definitions, theory, practices, and future directions. Contemporary Educational Psychology, 61, https://doi.org/10.1016/j.cedpsych.2020.101860.

Schunk, D. H., \& Meece, J. L. (2006). Self-efficacy development in adolescence. In F. Pajares \& T. Urdan (Eds.), Self-efficacy beliefs of adolescents, 71-96. Greenwich, CT: Information Age Publishing.

Schunk, D. H., \& Zimmerman, B. J. (2012). Motivation and self-regulated learning: Theory, research, and applications. New York, NY: Routledge.

Standage, M., Duda, J.L., \& Ntoumanis, N. (2005). A test of self-determination theory in school physical education. British Journal of Educational Psychology, 75, 411-433.

Steele, C. M. (1997). A threat in the air: how stereotypes shape intellectual identity and performance. The American Psychologist, 52(6), 613-629. doi: 10.1037//0003066x.52.6.613.

Taylor, G., Jungert, T., Mageau, G. A., Schattke, K., Dedic, H., Rosenfield, S., \& Koestner, R. (2014). A self-determination theory approach to predicting school achievement over time: The unique role of intrinsic motivation. Contemporary Educational Psychology, 39, 342-358.

Tian, L., Chen, H., \& Huebner, E. S. (2014). The longitudinal relationships between basic psychological needs satisfaction at school and school-related subjective wellbeing in adolescents. Social Indicators Research, 119(1), 353-372.

Vansteenkiste, M., Niemiec, C. P., \& Soenens, B. (2010). The development of the five mini-theories of self-determination theory: An historical overview, emerging trends, and future directions. Advances in motivation and achievement, 16, 105165.

Watt, H. M. G. (2004). Development of adolescents' self-perceptions, values, and task perceptions according to gender and domain in 7th-through 11th-grade Australian students. Child Development, 75, 1556-1574, doi: 10.1111/j.1467-8624.2004. 00757.x.

Wentzel, K.R., \& Miele, D.B. (2016). Handbook of motivation at school- second edition. Routledge, New York.

Zimmerman, B.J., \& Kitsantas, A. (1997). Developmental phases in self-regulation: shifting from process goals to outcome goals. Cited in Bong, M., \& Clark, R. E. 1999. Comparison between self-concept and self-efficacy in academic motivation research. Educational Psychologist, 34(3), 139-153. 